\title{
Effects of Hydroponics Systems on Growth, Yield and Quality of Zucchini (Cucurbita pepo L.)
}

\author{
Lungile T. Shongwe ${ }^{1}$, Michael T. Masarirambi ${ }^{1}$, Tajudeen O. Oseni ${ }^{1}$, Paul K. Wahome ${ }^{1}$, Kwanele A. Nxumalo ${ }^{1}$ \\ \& Phumlani I. Gule ${ }^{1}$ \\ ${ }^{1}$ Department of Horticulture, Faculty of Agriculture, Luyengo Campus, University of Swaziland, P.O. Luyengo \\ M205, Eswatini
}

Correspondence: Michael T. Masarirambi, Department of Horticulture, Faculty of Agriculture, Luyengo Campus, University of Eswatini, P.O. Luyengo M205, Eswatini. E-mail: mike@ uniswa.sz

Received: July 26, 2019 Accepted: August 9, $2019 \quad$ Online Published: September 19, 2019

doi:10.5539/jps.v8n2p62 URL: https://doi.org/10.5539/jps.v8n2p62

\begin{abstract}
There is dearth of information pertaining to hydroponics production of zucchini in the Kingdom of Eswatini. The objective of this study was to determine the effects of hydroponics systems on growth, yield and nutritional content of zucchini. The research was conducted in three greenhouses of the Horticulture Department, Faculty of Agriculture, Luyengo Campus at the University of Eswatini between July and October 2018. The experiment was laid out in a split-plot design replicated four times. Three hydroponics systems were used as the main plots, i.e. elevated tray, ground lay bed and Nutrient Film Technique (NFT) systems. The sub-plots were allocated to the three varieties, i.e., Amanda, Hygreen and Terminator. The zucchini grown in elevated tray hydroponics system had the highest yield in all the varieties compared to the other hydroponics systems. The results showed that there were significant differences in the growth, yield and nutritional content of zucchini cultivars grown in the different hydroponics systems. The tallest plants $(26.1 \mathrm{~cm})$ were obtained in cultivar Terminator grown in the elevated tray system and the highest number of leaves (15) was obtained in cultivar Terminator grown in the elevated tray system. Cultivar Terminator grown in the elevated tray system had the highest total yield (15.8 tons/ha) while Hygreen plants produced in the NFT system recorded the lowest total yield (1.04 tons/ha). There were no significant differences in the iron content of zucchini among the cultivars grown in the different hydroponics systems. The results of this study revealed that different zucchini cultivars responded differently when grown in the different hydroponics systems. Therefore based on the results of this study it is recommended that Terminator zucchini cultivar can be produced in the elevated tray hydroponics system.
\end{abstract}

Keywords: hydroponics, iron content, vegetative growth, yield, zucchini

\section{Introduction}

Zucchini (Cucurbita pepo L.) belong to the family Cucurbitaceae a member of cucumber, pumkins, gourds, melon, acorn, cocozelle, straightneck, scallop, crockneck and ornamental gourd (Lata et al., 2017). It is grown throughout the world in both temperate and tropical climatic zones. Zucchini originated in America and is available in the market in yellow, light green or green colours. The word zucchini comes from the Italian zucchino, meaning a small squash. The term squash comes from the Indian skutasquash meaning (green thing eaten green). Squash was one of the main foods the Native Americans ate along with corn and beans (Narke et al., 2015). It is a warm but short-season crop compared to other cucurbit fruits, such as melons and cucumbers (Lata et al., 2017). It is monoecious, which means that the male (stamens, shedding pollen) and female (pistil and ovary, forming the fruit) organs are borne in separate flowers on the same plant (Wang et al., 2007). Only the female flowers can bear fruit and honeybees are the primary pollinators. The fruit grows from the base of the female flower on a short stem. Once fruit is set, zucchini can grow up to $2.5 \mathrm{~cm}$ per day (Schonbeck and Farmer, 2010).

Hydroponics is the growing of plants without soil and it permits a good control of plant growth and development, and is currently in practice all over the world (Rouphael et al., 2004). It can also be defined as the science of growing plants using a solution of suitable nutrients instead of soil (Wahome et al., 2011). This can either be done through the use of none soil growing medium or no growing medium at all. The plants thrive on the water solution only. Hydroponics were first used in the Hanging Gardens of Babylon where plants were grown in a 
steady stream of water (Wahome et al., 2010). However, soilless culture requires frequent irrigation and high fertilization rates, and when used with free drainage (open system) it can result in loss of water and nutrients leading to negative financial consequences and contamination of ground and surface water resources. To solve this problem, growers have to adopt re-circulation of the nutrient solution. Various types of closed soilless systems have been developed for containerized crops. The most widely used are the surface system (drip-irrigation) and the sub-irrigation system (Ebb-and-flow benches, capillary mats, trough benches and flooded floors) (Rouphael, 2006).

Squash are generally open-field cultivated where climate, insect and disease pressures create challenging conditions for the grower (Shaw and Cantliff, 2005). To overcome these challenges zucchini may be grown in hydroponics. The soilless culture technique allows the achievement of high yields and less use of pesticides (Suvo et al., 2016). Zucchini has various health benefits to humans as well as medicinal potentials (Mohammed et al., 2011). It is rich in nutrients and bioactive compounds contents such as phenolics, flavonoids, vitamins (including $\beta$-carotene, vitamin $\mathrm{A}$, vitamin $\mathrm{B} 2, \alpha$-tocopherol, vitamin $\mathrm{C}$, and vitamin $\mathrm{E}$ ), amino acids, carbohydrates and minerals (especially potassium), and it is low in energy content (about $17 \mathrm{kcal} / 100 \mathrm{~g}$ of fresh pumpkin) and has large amount of fiber (Graifernberg et al., 1996). Zucchini squash is an important vegetable as its fruit, flower and leaves are edible. The peel is where many of the nutrients are hence peeling of the skin is not recommended.

Baby vegetable production is an intensive activity. The market demands consistency in production and this can be achieved through the use of hydroponics in protected cultivation. Greenhouse crops emerge as an alternative for the seasonality of production and increase in productivity since crops are not exposed to environmental variability (Maller et al., 2013). Crop production in an open field is susceptible to extreme solar radiation, high rainfall, weed competition, pest and disease infestations. Thus, hydroponics helps to reduce most of this conditions, including the control of chemicals sprayed hence there is reduction of chemical residues in the produce. High rainfall damages young plants, flowers and fruit setting in an open field (Ng'etich et al., 2013). Hydroponics growing systems have been developed to get higher yields and quality, to preserve water and land, to save labour and to protect the environment (Inden and Torres, 2004) partly in order to achieve sustainable development goals (SDGs) pertaining to people and planet earth. The high productivity of the plants in a hydroponic system is due to the direct supply of water and nutrients, which must be adequate to all the stages of the production process, since the nutritional status influences the biomass production and fruit quality (RSA Department of Agriculture, 2011; Yoshida et al., 1997). Hydroponics systems typically have a much smaller root zone volume, greater water-holding capacity, more available water, lower moisture tension, greater hydraulic conductivity, and a higher dissolved oxygen concentration in the irrigation solution (Rodrigo et al., 2012; Rouphael and Colla, 2009). Typically soil contains a multitude of substances that act as a buffer to chemical changes (Lata et al, 2017). Vegetable production in Eswatini is seasonal and farmers produce maize in summer and vegetables in winter. Growing of plants in soil is unpredictable due to changing temperatures, moisture holding capacity, availability of nutrients, root aeration, diseases and pest problems (Sihlongonyane et al., 2018a). In soilless production system, many types of growing media or substrates such as rockwool, perlite, vermiculite and peat have been used to grow many kinds of crops (Rouphael et al., 2004).

The information regarding the hydroponics systems and suitable zucchini varieties that can be planted in greenhouses is not available under local climatic conditions. There is decline in the availability of suitable land and good soil for crop production in Eswatini resulting from adverse effect of climate change, urbanization, industrialization and ever increasing population (Sihlongonyane et al., 2018b). Due to climate change, it is now very difficult to comply with cropping plans and this result in farmers failing to supply their markets on the agreed time and end up losing these markets due to inconsistency. Areas with poor soils are hardly being utilized yet the introduction of greenhouses areas can help utilize them. Zucchini grown in the open is exposed to fruit fly especially if the fields are next to an orchard with fruits like pawpaw and mango. The quality of the zucchini fruit is also compromised through the use of irrigation systems like sprinkler irrigation due to disease prevalence. Harvesting of zucchini fruits in hydroponics can be done on daily basis regardless of bad weather conditions, while in open field, it can be difficult to harvest on rainy days and also heavy droplets can make the zucchini fruit dirty (Kolota and Balbirz, 2015).

\section{Materials and Methods}

\subsection{Experimental Site and Plant Materials}

The research was conducted in three greenhouses in the Horticulture Department, Faculty of Agriculture, Luyengo Campus of the University of Eswatini between July and October 2018. Luyengo is located in Manzini 
region in the Middleveld agroecological zone at $26^{\circ} 34^{\prime} \mathrm{S}$ and $31^{\circ} 12^{\prime} \mathrm{E}$ at an altitude of $730 \mathrm{~m}$ above sea level. The average temperatures $27^{\circ} \mathrm{C}$ in summer and $15^{\circ} \mathrm{C}$ in winter. Mean annual precipitation is $890 \mathrm{~mm}$ with most of the rain falling between October and March. The soil type is an oxisol (M-set) of the Malkerns series (Mudorch, 1970). Zucchini seeds of three F1 hybrid zucchini namely Amanda, Hygreen and Terminator were obtained from the National Agricultural Marketing Board (NAMBOARD), Matsapha, Eswatini. Amanda was supplied by Alliance Seeds, from Durban in South Africa, Hygreen was supplied by Hygrotech, in Durban, South Africa and Terminator was from SeedcoR, from Durban in South Africa. The seeds were germinated in seed trays using compost and transplanted three weeks after planting into the different hydroponics systems as described in Table 1. The plants were then supplied with the nutrient solution after transplanting.

\subsection{Experimental Design}

The experiment was laid out in a split-plot design replicated four times. A total of thirty-six plots were used. Three hydroponics systems were used as the main plots, i.e. elevated tray, ground lay bed and Nutrient Film Technique (NFT) systems. The sub-plots were allocated to the three varieties, i.e., Amanda, Hygreen and Terminator.

\subsection{Data Collection}

Four randomly selected plants were sampled per block for data collection and the same plants were used throughout the duration of the experiment. Vegetative data collection was done three weeks after trans-planting (WAT) and then fortnightly until harvesting. The data collected included: plant height, number of leaves, chlorophyll content index, fresh and dry mass of shoots and roots, number of flowers, fruit yield, number of fruits per plant, fruit length and fruit diameter. Plant height was measured using a meter ruler from three WAT and thereafter fortnightly until harvesting. Fully expanded leaves of zucchini were counted from four tagged plants per block to get the number of leaves and then average was calculated to get the number of leaves per plant. A chlorophyll meter (SPAD-502 meter, Tung Yung LTD, Beijing, China) was used to determine the chlorophyll content index of the leaves per sampled plants. Leaves were placed in between the CCM lever and a CCI value was displayed on the screen and recorded; readings were taken from the third WAT then after every two weeks. The fresh mass of shoots and roots were measured using an electronic beam balance. They were then dried at $70^{\circ} \mathrm{C}$ using an oven (Biochrom LTD, Leeds, England). After 72 hours, the plants were then re-weighed to get the dry mass. Through observation and proper counting the number of flowers were recorded per tagged plant. An average was calculated to get the number of flowers per plant. Total fruit yield, marketable yield and unmarketable yield per plant were determined by grading and weighing harvested fruits from the sample plants periodically and the average fruits weight per plant was calculated. A balance scale was used to take the mass of fruit per plant. The yield was expressed in tons/ha. Harvested fruit from the tagged plants were sliced into thin slices and packed in brown bags, weighed and placed in an oven maintained at $75^{\circ} \mathrm{C}$ for 72 hours, thereafter the samples were weighed to get the final weight. The dry matter was expressed in percentage of the fresh weight.

Number of fruits per plant were counted and recorded in an all the treatments. Fruit length of zucchini fruit was measured using a tape measure and the readings were recorded. A vernier calliper was used to measure the fruit diameter.

Determination of minerals in zucchini fruit was done using the wet digestion method (AOAC, 2000). The samples were oven dried at $72^{\circ} \mathrm{C}$ for 48 hours. Each sample was then milled using a blender (Essentials LTD, Hong Kong). A sample weighing $1.0 \mathrm{~g}$ was transferred to $100 \mathrm{ml} \mathrm{Kjeldahl} \mathrm{flasks.} \mathrm{Concentrated} \mathrm{sulphuric} \mathrm{acid} \mathrm{(5} \mathrm{ml)} \mathrm{was} \mathrm{added}$ into the Kjeldahl flasks, and then $2.5 \mathrm{ml}$ of concentrated nitric acid was added and mixed thoroughly with the organic material. The flasks were then placed on the digestion rack, and the heat and fume-hood fan were turned on. Heating was done until the organic material turned to golden brown or reddish. The samples were then allowed to cool. Perchloric acid $(1 \mathrm{~mL})$ was added per sample and heating vigorously was done until the end point was reached when the solution turned from reddish to clear/yellowish. The contents of the digestion tube were transferred to $100 \mathrm{ml}$ volumetric flask. Deionized water was used to make up to the mark. A blank was prepared using the same reagents. The sample $(1 \mathrm{~mL})$ was transferred into a test tube and then $9 \mathrm{ml}$ of distilled water was added. Standards were prepared at $0.2,0.4$, and 0.6 at $1 \mathrm{~mL}$ and subjected to Atomic Absorption (AA) Spectroscopy where the reading for concentration were observed and recorded. Minerals determined using the above method included calcium, iron, manganese and phosphorus.

The determination of crude protein in zucchini fruit was carried out at the Nutrition Laboratory, Luyengo Campus at the University of Eswatini. The samples were oven dried at $72^{\circ} \mathrm{C}$ for 48 hours. Each sample was then milled to powder using a blender. A sample $(1.0 \mathrm{~g})$ was transferred to $800 \mathrm{ml}$ Kjeldahl flask. Then $13 \mathrm{ml}$ concentrated sulphuric acid and $10 \mathrm{~g}$ of catalyst mixture $(5 \% \mathrm{CuSO} 4+94.8 \% \mathrm{~K} 2 \mathrm{SO} 4+0.2 \% \mathrm{Se})$ were added. The flasks were 
then placed on the digestion rack, and the heat and fume-hood fan were turned on. Heating was done until the solution became clear (AOAC, 2000). Before the digests solidified, $50 \mathrm{ml}$ of distilled water was added while cooling under running water. A $50 \mathrm{ml}$ volume of boric acid containing a few drops of indicator (bromocresol green). The digest was distilled using $40 \%$ sodium hydroxide and the distillate was collected in a $25 \mathrm{ml}$ boric acid solution, then the distillate was titrated using $0.1 \mathrm{~N}$ sulphuric acid to a neutral faint purple distillate colour and the volume of titrant was recorded. Then the results were calculated using the following equations:

$\%$ Nitrogen $(\mathrm{N})=((\mathrm{Ml}$ acid titrated-Ml blank titrated $) \times$ Acid Normally x $0.014 \times 100) /$ Weight of sample.

\subsection{Data Analysis}

Data collected was subjected to Analysis of Variance (ANOVA) using Statistical Package Genstat $3^{\text {rd }}$ Ed. (Payne, 2009). Means where the F-test showed significant differences were separated using the Duncan's New Multiple Range Test (DNMRT) at 5\% level of significance (Steel et al., 1997).

\section{Results}

\subsection{Plant Height}

There were no significant $(\mathrm{P}>0.05)$ differences in plant height among the cultivars grown in the different hydroponics systems (Table 1). At 9 WAT, the highest plant height $(26,1 \mathrm{~cm})$ was observed in cultivar Terminator planted in the elevated tray system while the lowest plant height $(19.1 \mathrm{~cm})$ was observed in cultivar Terminator grown in the NFT system (Table 1).

Table 1. Effects of hydroponics system and variety on the plant height $(\mathrm{cm})$ of zucchini plants

\begin{tabular}{llllll}
\hline & & \multicolumn{4}{l}{ Weeks after transplanting } \\
\hline Hydroponics Systems & Cultivar & 3 & 5 & 7 & 9 \\
\hline Elevated Tray & Amanda & $5.31 \mathrm{~d}$ & $6.81 \mathrm{c}$ & $23.43 \mathrm{~b}$ & $19.4 \mathrm{~cd}$ \\
& Hygreen & $7.25 \mathrm{c}$ & $8.47 \mathrm{bc}$ & $25.38 \mathrm{ab}$ & $23.9 \mathrm{~b}$ \\
& Terminator & $8.10 \mathrm{bc}$ & $8.75 \mathrm{bc}$ & $29.19 \mathrm{a}$ & $26.1 \mathrm{a}$ \\
Ground Lay Bed & Amanda & $4.63 \mathrm{de}$ & $8.63 \mathrm{bc}$ & $21.60 \mathrm{~b}$ & $22.6 \mathrm{c}$ \\
& Hygreen & $4.56 \mathrm{de}$ & $8.03 \mathrm{c}$ & $20.32 \mathrm{~b}$ & $19.8 \mathrm{~d}$ \\
& Terminator & $3.79 \mathrm{e}$ & $7.72 \mathrm{c}$ & $20.72 \mathrm{~b}$ & 20.9 \\
NFT & Amanda & $8.63 \mathrm{~b}$ & $10.41 \mathrm{ab}$ & $10.82 \mathrm{a}$ & $19.4 \mathrm{~d}$ \\
& Hygreen & $9.94 \mathrm{a}$ & $10.36 \mathrm{ab}$ & $11.19 \mathrm{a}$ & $20.9 \mathrm{~cd}$ \\
& Terminator & $10.56 \mathrm{a}$ & $11.44 \mathrm{a}$ & $11.78 \mathrm{a}$ & $19.1 \mathrm{~cd}$ \\
\hline
\end{tabular}

Mean values within the same column followed by the same letter are not significantly. Mean separation by DNMRT at $\mathrm{P}=0.05$.

\subsection{Number of Leaves}

There were significant $(\mathrm{P}<0.05)$ differences in number of leaves among the cultivars grown in the different hydroponics systems (Table 2). At 9 WAT highest number of leaves (15) was observed in cultivar Terminator planted in the elevated tray system while the lowest number of leaves (10) was observed in cultivar Terminator grown in the ground lay bed system (Table 2).

Table 2. Effects of hydroponics system and variety on the number of leaves of zucchini plants

\begin{tabular}{llllll}
\hline & & \multicolumn{5}{c}{ Weeks after transplanting } \\
\hline Hydroponic Systems & Cultivar & $\mathbf{3}$ & $\mathbf{5}$ & $\mathbf{7}$ & $\mathbf{9}$ \\
\hline Elevated Tray & Amanda & $7 \mathrm{a}$ & $10 \mathrm{ab}$ & $11 \mathrm{ab}$ & $13 \mathrm{~b}$ \\
& Hygreen & $8 \mathrm{a}$ & $10 \mathrm{ab}$ & $11 \mathrm{abc}$ & $12 \mathrm{~cd}$ \\
\multirow{4}{*}{ Ground Lay Bed } & Terminator & $8 \mathrm{a}$ & $11 \mathrm{a}$ & $13 \mathrm{a}$ & $15 \mathrm{a}$ \\
& Amanda & $5 \mathrm{c}$ & $9 \mathrm{c}$ & $9 \mathrm{bc}$ & $12 \mathrm{de}$ \\
& Hygreen & $5 \mathrm{c}$ & $7 \mathrm{c}$ & $9 \mathrm{bc}$ & $12 \mathrm{de}$ \\
NFT & Terminator & $5 \mathrm{bc}$ & $8 \mathrm{c}$ & $8 \mathrm{c}$ & $12 \mathrm{cde}$ \\
& Amanda & $7 \mathrm{ab}$ & $9 \mathrm{bc}$ & $10 \mathrm{bc}$ & $11 \mathrm{ef}$ \\
& Hygreen & $6 \mathrm{bc}$ & $8 \mathrm{c}$ & $9 \mathrm{bc}$ & $11 \mathrm{f}$ \\
& Terminator & $5 \mathrm{bc}$ & $7 \mathrm{c}$ & $9 \mathrm{bc}$ & $11 \mathrm{gh}$ \\
\hline
\end{tabular}

Mean values within the same column followed by the same letter are not significantly different from each other. Mean separation by DNMRT at $\mathrm{P}=0.05$. 


\subsection{Chlorophyll Content Index}

There were significant $(\mathrm{P}<0.05)$ differences in chlorophyll content index among the cultivars grown in the different hydroponics systems (Table 3). At 9 WAT, the highest chlorophyll content (60.7 CCI) was observed in cultivar Terminator planted in the ground lay bed system while the lowest chlorophyll content index (34.8 CCI) was observed in cultivar Hygreen grown in the ground lay bed system (Table 3).

Table 3. Effects of hydroponics system and variety on the chlorophyll content index of zucchini plants

\begin{tabular}{llllll}
\hline & \multicolumn{5}{c}{ Weeks after transplanting } \\
\hline Hydroponic Systems & Cultivar & 3 & 5 & 7 & \multicolumn{1}{c}{9} \\
\hline Elevated Tray & Amanda & $57 \mathrm{~b}$ & $59.3 \mathrm{bc}$ & $61.58 \mathrm{ab}$ & $57.1 \mathrm{~b}$ \\
& Hygreen & $56.77 \mathrm{bc}$ & $58.6 \mathrm{~d}$ & $59.38 \mathrm{~b}$ & $56.9 \mathrm{~b}$ \\
& Terminator & $56.88 \mathrm{c}$ & $59.03 \mathrm{~b}$ & $59.30 \mathrm{~b}$ & $57.1 \mathrm{~b}$ \\
Ground Lay Bed & Amanda & $57.25 \mathrm{~b}$ & $58.90 \mathrm{bc}$ & $59.23 \mathrm{~b}$ & $57.27 \mathrm{~b}$ \\
& Hygreen & $56.07 \mathrm{c}$ & $38.07 \mathrm{bc}$ & $58.57 \mathrm{bc}$ & $56.07 \mathrm{~b}$ \\
& Terminator & $60.67 \mathrm{a}$ & $62.45 \mathrm{a}$ & $62.90 \mathrm{a}$ & $60.7 \mathrm{a}$ \\
NFT & Amanda & $39.47 \mathrm{~d}$ & $41.65 \mathrm{e}$ & $42.15 \mathrm{~d}$ & $39.47 \mathrm{c}$ \\
& Hygreen & $34.77 \mathrm{f}$ & $39 \mathrm{de}$ & $39.55 \mathrm{de}$ & $34.8 \mathrm{~d}$ \\
& Terminator & $37.97 \mathrm{e}$ & $40.12 \mathrm{f}$ & $40.46 \mathrm{~d}$ & $37.97 \mathrm{c}$
\end{tabular}

Mean values within the same column followed by the same letter are not significantly different from each other. Mean separation by DNMRT P $=0.05$.

\subsection{Number of Flowers}

There were significant $(\mathrm{P}<0.05)$ differences in the number of flowers among the cultivars grown in the different hydroponics systems (Table 4). At 9 WAT, the highest number of flowers (8) was observed in cultivarAmanda planted in the elevated tray system while the lowest number of flowers per plant (5.5) was observed in cultivar Terminator grown in the NFT system (Table 4).

Table 4. Effects of hydroponics system and variety on the number of flowers of zucchini plants

\begin{tabular}{llllll}
\hline & & \multicolumn{4}{l}{ Weeks after transplanting } \\
\hline Hydroponic Systems & Cultivar & 3 & 5 & 7 & 9 \\
\hline Elevated Tray & Amanda & $3 \mathrm{ab}$ & $7 \mathrm{ab}$ & $6 \mathrm{a}$ & $8 \mathrm{a}$ \\
& Hygreen & $5 \mathrm{a}$ & $8 \mathrm{a}$ & $7 \mathrm{a}$ & $7.5 \mathrm{a}$ \\
\multirow{3}{*}{ Ground Lay Bed } & Terminator & $4 \mathrm{a}$ & $7 \mathrm{ab}$ & $7 \mathrm{a}$ & $7.5 \mathrm{a}$ \\
& Amanda & $4 \mathrm{c}$ & $6 \mathrm{bc}$ & $6 \mathrm{a}$ & $6.5 \mathrm{a}$ \\
& Hygreen & $3 \mathrm{bc}$ & $5 \mathrm{c}$ & $6 \mathrm{a}$ & $6.5 \mathrm{a}$ \\
\multirow{5}{*}{ NFT } & Terminator & $4 \mathrm{bc}$ & $6 \mathrm{bc}$ & $5 \mathrm{a}$ & $6.25 \mathrm{a}$ \\
& Amanda & $1 \mathrm{a}$ & $4 \mathrm{abc}$ & $6 \mathrm{a}$ & $6 \mathrm{~b}$ \\
& Hygreen & $2 \mathrm{ab}$ & $5 \mathrm{bc}$ & $5 \mathrm{a}$ & $6 \mathrm{~b}$ \\
& Terminator & $1 \mathrm{ab}$ & $4 \mathrm{abc}$ & $6 \mathrm{a}$ & $5.5 \mathrm{c}$ \\
\hline
\end{tabular}

Mean values within the same column followed by the same letter are not significantly different from each other. Mean separation by DNMRT at $\mathrm{P}=0.05$.

\subsection{Number of Fruits}

There were significant $(\mathrm{P}<0.05)$ differences in the number of fruits per plant among the cultivars grown in the different hydroponics systems (Table 5). The highest number of fruits (12) was observed in Terminator cultivar planted in the elevated tray system while cultivar Amanda and Hygreen grown in the NFT system had the lowest (1.8 and 1.2) number of fruits per plant respectively (Table 5).

\subsection{Fruit Length and Diameter}

There were significant $(\mathrm{P}<0.05)$ differences in the fruit length among the cultivars grown in the different hydroponics systems (Table 5). The highest fruit length of zucchini fruit was observed in cultivar Hygreen planted in the elevated $(10.23 \mathrm{~cm})$ tray system while cultivar Hygreen grown in the NFT system had the lowest $(6,1 \mathrm{~cm})$ fruit length (Table 5). There were significant $(\mathrm{P}<0.05)$ differences in the fruit diameter among the cultivars grown in the different hydroponics systems (Table 5). The highest fruit diameter $(2.1 \mathrm{~cm})$ of zucchini fruit was observed in cultivar Hygreen planted in the elevated tray system while cultivar Hygreen grown in the 
NFT system had the lowest fruit diameter $(1.2 \mathrm{~cm})$ (Table 5).

Table 5. Effects of hydroponics system and variety on the number of fruit, fruit length $(\mathrm{cm})$ and fruit diameter $(\mathrm{cm})$

\begin{tabular}{lllll}
\hline Hydroponic Systems & Cultivar & Number of fruit & Fruit length $(\mathrm{cm})$ & Fruit diameter $(\mathrm{cm})$ \\
\hline Elevated Tray & Amanda & $10 \mathrm{a}$ & $9.16 \mathrm{a}$ & $1.83 \mathrm{a}$ \\
& Hygreen & $6 \mathrm{~b}$ & $10.28 \mathrm{a}$ & $2.05 \mathrm{a}$ \\
& Terminator & $12 \mathrm{a}$ & $8.95 \mathrm{a}$ & $1.88 \mathrm{a}$ \\
Ground Lay Bed & Amanda & $4 \mathrm{~cd}$ & $8.79 \mathrm{a}$ & $1.7 \mathrm{a}$ \\
& Hygreen & $4 \mathrm{~b}$ & $8.41 \mathrm{ab}$ & $1.78 \mathrm{a}$ \\
& Terminator & $2 \mathrm{de}$ & $8.89 \mathrm{a}$ & $1.76 \mathrm{a}$ \\
NFT & Amanda & $2 \mathrm{e}$ & $9.15 \mathrm{a}$ & $1.94 \mathrm{~b}$ \\
& Hygreen & $1 \mathrm{e}$ & $6.13 \mathrm{~b}$ & $1.23 \mathrm{a}$ \\
& Terminator & $3 \mathrm{de}$ & $8.51 \mathrm{ab}$ & $1.98 \mathrm{a}$ \\
\hline
\end{tabular}

Mean values within the same column followed by the same letter are not significantly different from each other. Mean separation by DNMRT at $\mathrm{P}=0.05$.

\subsection{Total Yield}

There were significant $(\mathrm{P}<0.05)$ differences in the total yield among the cultivars grown in the different hydroponics systems (Table 6). At 9WAT, the highest total yield (15.8 t/ha) was observed in cultivar Terminator planted in the elevated tray system while cultivar Hygreen grown in the NFT system had the lowest total yield (1.2 t/ha) (Table 6).

\subsection{Marketable Yield and Unmarketable Yield}

There were significant $(\mathrm{P}<0.05)$ differences in the marketable yield per plant among the cultivars grown in the different hydroponics systems (Table 6). The highest marketable yield (14.66 t/ha) of zucchini fruit was observed in cultivar Terminator planted in the elevated tray system while the cultivar Hygreen grown in the NFT system had the lowest marketable yield (1.19 t/ha) (Table 6). There were no significant $(\mathrm{P}>0.05)$ differences in the unmarketable yield per plant among the cultivars grown in the different hydroponics systems (Table 6).

Table 6. Effects of hydroponics system and variety on the fruit yield (t/ha) of zucchini plants

\begin{tabular}{lllll}
\hline Hydroponic Systems & Cultivar & Total yield & Marketable yield & Unmarketable yield \\
\hline Elevated Tray & Amanda & $12,19 \mathrm{~b}$ & $10,99 \mathrm{~b}$ & $1,2 \mathrm{a}$ \\
& Hygreen & $11,43 \mathrm{~b}$ & $10,47 \mathrm{~b}$ & $0,96 \mathrm{a}$ \\
\multirow{4}{*}{ Ground Lay Bed } & Terminator & $15,78 \mathrm{a}$ & $14,66 \mathrm{c}$ & $1,12 \mathrm{a}$ \\
& Amanda & $4,61 \mathrm{c}$ & $3,95 \mathrm{c}$ & $0,66 \mathrm{a}$ \\
\multirow{5}{*}{ NFT } & Hygreen & $4,51 \mathrm{c}$ & $4,01 \mathrm{c}$ & $0,50 \mathrm{a}$ \\
& Terminator & $4,03 \mathrm{~cd}$ & $3,29 \mathrm{~cd}$ & $0,74 \mathrm{a}$ \\
& Amanda & $1,81 \mathrm{de}$ & $1,58 \mathrm{~d}$ & $0,23 \mathrm{a}$ \\
& Hygreen & $1,19 \mathrm{e}$ & $1,19 \mathrm{~d}$ & $0,00 \mathrm{a}$ \\
& Terminator & $2,60 \mathrm{cde}$ & $1,96 \mathrm{~cd}$ & $0,64 \mathrm{a}$ \\
\hline
\end{tabular}

Mean values within the same column followed by the same letter are not significantly different from each other. Mean separation by DNMRT at $\mathrm{P}=0.05$.

\subsection{Dry Matter Content}

There were no significant $(\mathrm{P}>0.05)$ differences in dry matter content of different zucchini cultivars in the different hydroponics systems (Table 7). The highest dry matter percentage (7.9\%) was obtained from Hygreen cultivar produced in ground lay beds while the lowest dry matter percentage $(4.1 \%)$ was found in Amanda also grown in ground lay beds (Table 7).

\subsection{Fresh and Dry Shoot Masses}

There were significant $(\mathrm{P}<0.05)$ differences in the fresh shoot mass of zucchini among the cultivars grown in the different hydroponics systems (Table 7). The highest fresh shoot mass (692.1g) was observed in cultivar Hygreen planted in the elevated tray system while cultivar Amanda grown in the NFT system had the lowest fresh shoot mass per plant $(67 \mathrm{~g})$ of zucchini (Table 7). There were significant $(\mathrm{P}<0.05)$ differences in the dry 
shoot mass of zucchini among the cultivars grown in the different hydroponics systems (Table 7). The highest dry shoot mass $(66.7 \mathrm{~g})$ of zucchini plant was observed in cultivar Hygreen planted in the elevated tray system while cultivar Amanda grown in the ground lay bed system had the lowest $(9.9 \mathrm{~g})$ dry shoot mass per plant of zucchini (Table 7).

Table 7. Effects of hydroponics system and variety on the dry matter content (\%), fresh and dry shoot mass (g) of zucchini plants

\begin{tabular}{lllll}
\hline Hydroponic Systems & Cultivar & Dry matter content $(\%)$ & Fresh shoot mass $(\mathrm{g})$ & Dry shoot mass $(\mathrm{g})$ \\
\hline Elevated Tray & Amanda & $6,28 \mathrm{a}$ & $636,03 \mathrm{a}$ & $55,2 \mathrm{a}$ \\
& Hygreen & $5,23 \mathrm{a}$ & $692,11 \mathrm{a}$ & $66,72 \mathrm{a}$ \\
\multirow{3}{*}{ Ground Lay Bed } & Terminator & $6,65 \mathrm{a}$ & $558,8 \mathrm{a}$ & $47,9 \mathrm{ab}$ \\
& Amanda & $4,1 \mathrm{a}$ & $146,3 \mathrm{~b}$ & $9,95 \mathrm{c}$ \\
& Hygreen & $7,89 \mathrm{a}$ & $160,51 \mathrm{~b}$ & $17,9 \mathrm{c}$ \\
NFT & Terminator & $5,3 \mathrm{a}$ & $242,88 \mathrm{~b}$ & $12,28 \mathrm{c}$ \\
& Amanda & $4,82 \mathrm{a}$ & $67 \mathrm{~b}$ & $26,11 \mathrm{bc}$ \\
& Hygreen & $4,76 \mathrm{a}$ & $77,52 \mathrm{~b}$ & $10,53 \mathrm{c}$ \\
& Terminator & $4,89 \mathrm{a}$ & $194,78 \mathrm{~b}$ & $14 \mathrm{c}$ \\
\hline
\end{tabular}

Mean values within the same column followed by the same letter are not significantly different from each other. Mean separation by DNMRT $\mathrm{P}=0.05$.

\subsection{Fresh and Dry Root Masses}

There were significant $(\mathrm{P}<0.05)$ differences in the fresh root mass of zucchini among the cultivars grown in the different hydroponics systems (Table 8). The highest fresh root mass per plant (124.8 g ) of zucchini plant was observed in cultivar Amanda planted in the elevated tray system while cultivar Amanda grown in the NFT system had the lowest fresh root mass per plant $(15.9 \mathrm{~g})$ (Table 8). There were significant $(\mathrm{P}<0.05)$ differences in the dry root mass of zucchini among the cultivars grown in the different hydroponics systems (Table 8 ). The highest dry root mass per plant $(28.0 \mathrm{~g})$ of zucchini plant was observed in cultivar Hygreen planted in the elevated tray system while cultivar Amanda grown in the ground NFT system had the lowest dry root mass per plant $(4.8 \mathrm{~g})$ (Table 8$)$.

Table 8. Effects of hydroponics system and variety on the fresh and dry root mass $(\mathrm{g})$ of zucchini plants

\begin{tabular}{llll}
\hline Hydroponic Systems & Cultivar & Fresh root mass $(\mathrm{g})$ & Dry root mass $(\mathrm{g})$ \\
\hline Elevated Tray & Amanda & $124,77 \mathrm{a}$ & $25,73 \mathrm{ab}$ \\
& Hygreen & $116,71 \mathrm{ab}$ & $27,98 \mathrm{a}$ \\
\multirow{3}{*}{ Ground Lay Bed } & Terminator & $77,8 \mathrm{bc}$ & $8,5 \mathrm{~cd}$ \\
& Amanda & $47,09 \mathrm{~cd}$ & $16, \mathrm{cc}$ \\
& Hygreen & $50,4 \mathrm{~cd}$ & $10,2 \mathrm{~cd}$ \\
NFT & Terminator & $50,87 \mathrm{~cd}$ & $11,5 \mathrm{~cd}$ \\
& Amanda & $15,86 \mathrm{~d}$ & $4,75 \mathrm{~d}$ \\
& Hygreen & $17,48 \mathrm{~d}$ & $6,98 \mathrm{~cd}$ \\
\hline
\end{tabular}

Mean values within the same column followed by the same letter are not significantly different from each other. Mean separation by DNMRT at $\mathrm{P}=0.05$.

\subsection{Protein, Phosphorus and Iron Content}

There were significant $(\mathrm{P}<0.05)$ differences in the protein content of zucchini fruit among the cultivars grown in the different hydroponics systems (Table 9). The highest protein content $(5.3 \mathrm{mg}$ ) of zucchini plant was observed in cultivar Amanda planted in the NFT system while cultivar Hygreen grown in the ground lay bed system had the lowest protein content $(2.5 \mathrm{mg})$ (Table 9). There were significant $(\mathrm{P}<0.05)$ differences in the phosphorus content of zucchini fruit among the cultivars grown in the different hydroponics systems (Table 9). The highest phosphorus content $(10.1 \mathrm{mg})$ of zucchini plant was observed in cultivar Hygreen planted in the ground lay bed system while cultivar Terminator grown in the elevated tray system had the lowest phosphorus content $(1.4 \mathrm{mg})$. There were no significant $(\mathrm{P}>0.05)$ differences in the iron content of zucchini fruit among the cultivars grown in the different hydroponics systems (Table 9$)$. The amount of iron content was the same $(0.5 \mathrm{mg})$ in all the treatments and cultivars (Table 9). 


\subsection{Manganese and Calcium Content}

There were significant $(\mathrm{P}<0.05)$ differences in the manganese content of zucchini fruit among the cultivars grown in the different hydroponics systems (Table 9$)$. The highest manganese content $(0.07 \mathrm{mg})$ of zucchini fruit was observed in cultivar Hygreen grown in all the hydroponics systems. There were no significant $(\mathrm{P}>0.05)$ differences in the cultivar Amanda and Hygreen grown in all the hydroponics systems. There were significant ( $\mathrm{P}$ $<0.05$ ) differences in the calcium content of zucchini fruit among the cultivars grown in the different hydroponics systems.

Table 9: Effects of hydroponics system and variety on the protein, phosphorus and iron contents $(\mathrm{mg} / 100 \mathrm{~g})$ of zucchini plant

\begin{tabular}{lllllll}
\hline Hydroponic Systems & Cultivar & Protein & $\mathrm{P}$ & $\mathrm{Mn}$ & $\mathrm{Ca}$ & $\mathrm{Fe}$ \\
\hline Elevated Tray & Amanda & $3.08 \mathrm{f}$ & $2.04 \mathrm{~b}$ & $0.6 \mathrm{a}$ & $0.06 \mathrm{a}$ & $0.55 \mathrm{bc}$ \\
& Hygreen & $4.95 \mathrm{ab}$ & $3.43 \mathrm{~d}$ & $0.6 \mathrm{a}$ & $0.06 \mathrm{a}$ & $0.51 \mathrm{c}$ \\
& Terminator & $3.44 \mathrm{e}$ & $1.42 \mathrm{a}$ & $0.6 \mathrm{a}$ & $0.05 \mathrm{~b}$ & $0.55 \mathrm{ab}$ \\
Ground Lay Bed & Amanda & $5.28 \mathrm{a}$ & $4.13 \mathrm{f}$ & $0.6 \mathrm{a}$ & $0.06 \mathrm{a}$ & $0.55 \mathrm{a}$ \\
& Hygreen & $2.53 \mathrm{~g}$ & $10.09 \mathrm{i}$ & $0.6 \mathrm{a}$ & $0.04 \mathrm{c}$ & $0.53 \mathrm{~cd}$ \\
& Terminator & $4.54 \mathrm{c}$ & $3.16 \mathrm{c}$ & $0.6 \mathrm{a}$ & $0.05 \mathrm{~b}$ & $0.52 \mathrm{~cd}$ \\
NFT & Amanda & $4.34 \mathrm{~cd}$ & $6.14 \mathrm{~g}$ & $0.5 \mathrm{~b}$ & $0.05 \mathrm{~b}$ & $0.53 \mathrm{bc}$ \\
& Hygreen & $4.03 \mathrm{~d}$ & $8.88 \mathrm{~h}$ & $0.6 \mathrm{a}$ & $0.05 \mathrm{~b}$ & $0.53 \mathrm{~cd}$ \\
& Terminator & $4.92 \mathrm{i}$ & $3.78 \mathrm{e}$ & $0.6 \mathrm{a}$ & $0.05 \mathrm{a}$ & $0.52 \mathrm{~cd}$ \\
\hline
\end{tabular}

Mean values within the same column followed by the same letter are not significantly different from each other. Mean separation by DNMRT at $\mathrm{p}=0.05$.

\section{Discussion}

The highest plant height was obtained in cultivar Terminator grown in elevated tray system at 9 weeks after planting (WAP) and the shortest plant height were obtained from cultivar Terminator grown in the ground lay bed system. This is a result of the different surface area of the two systems; the elevated tray system has an extensive surface area for root development yet in the ground lay bed system the plants have limited surface area for root development. Plant height is the result of biochemical changes in the plant (Anwar et al., 2013). Xu et al. (2005), reported that increased leaf area implies higher light inception, increase the size of photosynthesizing surface area and dry matter production. The highest number of leaves was obtained in variety Terminator grown in the elevated tray system while the least number of leaves was obtained in the cultivar Terminator grown in the NFT system. The highest number of leaves observed in the elevated tray system could be attributed to higher vegetative growth as a result of the larger volume of the growing medium compared to the other system.

The highest chlorophyll content was obtained in cultivar Terminator grown in the ground lay bed system and the lowest chlorophyll content was obtained in cultivar Terminator grown in the NFT system. The direction of the different greenhouses can contribute to the chloropyll content index obtained due to the different amount of light entering the greenhouse. A study conducted by Endang et al. (2016) showed that the amount of chlorophyll content index increased with increased amount of nitrogen. Endang et al. (2016) also stated that chlorophyll content does not only affects photosynthesis but also affects the fruit colour. At 9 WAT the highest number of flowers was obtained in Amanda cultivar grown in the elevated tray system and the lowest number of flowers was obtained in Hygreen grown in the ground lay bed system. This can be a result of the different surface area of sawdust in the two systems, the elevated tray system had large surface area of sawdust than the ground lay bed system. The surface area can influence the water holding capacity of the medium. It is commonly thought that relatively low soil humidity during cucurbitaceae flower buds initiation favours their formation. Further growth of fruit (from the moment of setting), depends mainly on continuous water supply from soil (Saaata and Stepaniuk, 2012; Cardoso et al., 2017).

Terminator grown in the elevated tray system produced the highest number of fruits per plant while Hygreen and Amanda from the ground lay bed system produced the lowest number of fruit per plant. The results are similar to those of (Shaw and Cantliff, 2005; Sihlongonyane et al., 2018a; 2018b). This is due to the number of flowers produced in each treatment. There were no significant differences in the cultivar Amanda and Hygreen grown in all the hydroponics systems. At 9 WAT, the highest total yield was observed in cultivar Terminator planted in the elevated tray system while cultivar Hygreen grown in the ground lay bed system had the lowest total yield. The highest marketable yield of zucchini fruit was observed in cultivar Terminator planted in the elevated tray system 
while the cultivar Hygreen grown in the ground lay bed system had the lowest marketable yield of zucchini fruit. The highest unmarketable yield was observed in cultivar Amanda planted in the elevated tray system while Hygreen cultivar grown in the ground lay bed system had the lowest unmarketable yield of zucchini fruit. The results showed that most of the zucchini fruits were marketable hence rejects were very low, this can be due to the protected cultivation since the fruits were protected from harsh conditions. Similar results were reported by Mohammed et al. (2011); Carvajal et al. (2011).

The highest fruit length of zucchini was obtained from the Hygreen cultivar grown in the elevated tray system and the lowest fruit length was obtained from the hygreen grown from the ground lay bed system. The highest zucchini diameter was obtained from the Hygreen cultivar grown in the elevated tray system and the lowest diameter was obtained from the Hygreen grown from the ground lay bed system. The results of this study pertaining to fruit quality are similar to the previous findings of (Schonbeck and Farmer, 2010; Bruin et al., 2015)

Hygreen cultivar grown in the ground lay bed system had the highest dry matter content while the Amanda variety grown in the ground lay bed system had the lowest dry matter content. The Hygreen variety grown in the elevated tray system had the highest fresh shoot mass while Amanda variety grown in the NFT system had the lowest fresh shoot mass. The Hygreen variety grown in the elevated tray system had the highest dry shoot mass while Amanda variety grown in the ground lay bed system had the lowest dry shoot mass. The Amanda variety grown in the elevated tray system had the highest fresh root mass while Amanda variety grown in the NFT system had the lowest fresh root mass. The Hygreen variety grown in the elevated tray system had the highest dry root mass while Amanda variety grown in the NFT system had the lowest dry root mass. Cultivar differences in growth have been previously been reported (Shaw and Cantliff et al., 2005; Sihlongonyane et al., 2018a, 2018b).

Hygreen variety grown in the ground lay bed system had the highest phosphorus content while the Terminator grown in the elevated tray system had the lowest phosphorus content. The highest protein content was obtained from the variety Amanda produced in the ground lay bed and the lowest protein content was obtained from Hygreen grown in the ground lay bed. The Amanda cultivar grown in the elevated tray system had the highest calcium content with the Hygreen from the NFT system having the lowest calcium content. The highest manganese content of zucchini fruit was observed in cultivar hygreen grown in all the hydroponics systems. The results of this study pertaining to mineral composition are similar to previous findings of Rouphael and Colla (2005).

\section{Conclusion}

The highest marketable yield was obtained in cultivar Terminator grown in the elevated tray system. There is great potential for hydroponically produced zucchini based on the high yields obtained in the elevated tray system (15.8 tons/ha) which is way above the yields obtained in the open field ( 6.0 tons/ha). The fruit produced in hydroponics are clean, undamaged by wind or soil and harvesting is easily done on a daily basis.

\section{References}

Anwar, M., Sahito, H. A., \& Butt, J. (2013). Which soilless and soil -based media support the performance and quality of marigold most?. International Journal of Agricultural Policy and Research, 1(10), 298-304.

AOAC (2000). Official Methods of Analysis. Association of Official Analytical Chemists. Washington DC, USA

Bruin, W. D., Rossouw, W., \& Korstern, L. (2015). Comparison of safe alternative dipping treatments to maintain quality of zucchini. Journal of Food Quality, 39(2016), 109-115. https://doi.org/10.1111/jfq.12186

Cardoso, D. S. C. P., Sediyama, M. A. N., Fonseca, M. C. M., Poltronieri, Y., \& Neves, Y. F. (2017). Effect of concentration and $\mathrm{N}$ : $\mathrm{K}$ ratio in nutrient solution for hydroponic production of cucumber. Journal of Plant Science, 30(4), 818-824. https://doi.org/10.1590/1983-21252017v30n401rc

Carvajal, F., Martinez, C., Garrido, D., \& Jamilena, M. (2011). Differential response of zucchini varieties to low storage temperature. Scientia Horticulturae, 130(1), 90-96. https://doi.org/10.1016/j.scienta.2011.06.016

Endang, D. P., Kusminadi, F., Slamet, W., Darmawatt, A., \& Roesally, W. (2016). Differences in plant growth rate, chlorophyll content index and nitrate reductase in source N. of sweetcorn. International Proceedings of Chemical, Biological and Environmental Engineering, 92(4), 23-26.

Graifenberg, A., Botrini, L., Giustiniani, L., \& Lipucci Di Paola, M., (1996). Yield, growth and element content of zucchini squash grown under saline-sodic conditions. Journal of Horticultural Science, 71(2), 305-311. https://doi.org/10.1080/14620316.1996.11515409 
Inden, H., \& Torres, A. (2004). Comparison of four substrates on growth and quality of tomatoes. Acta Horticulturae, 644(644), 47-52. https://doi.org/10.17660/ActaHortic.2004.644.27

Kołota, E., \& Balbierz, A. (2015). Yield potential and fruit quality of scallop squash (Cucurbita pepo L . var. patissonina Greb . f . radiata Nois .) cultivars grown for processing. Acta. Agrobotanica, 68(3), 261-266. https://doi.org/10.5586/aa.2015.030

Lata, H., Khandenkar, R. G., Haldavanekar, D. C., Salvi, V. G., \& Salvi, B. R. (2017). Effect of spacing and fertilizer levels on growth and yield of zucchini (Cucurbita pepo L.) International Journal of Science and Nature, 8(4), 802-805.

Maller, A., Hara, A., de Olevera, J., Lorenzoni, M., \& Roberto, R. (2013). Fertigation of zucchini in greenhouse environments. Journal of Water Resources and Irrigation Management, 2(3), 143-148.

Mohammed, B. E., Ehsan, R., \& Amin, A. (2011). Climatic suitability of growing summer squash (Cucurbita pepo L.) as a medicinal plant in Iran. Journal of Science and Biology, 3(2), 39-46. https://doi.org/10.15835/nsb325846

Mudorch, G. (1970). Soils and Land Capability in Swaziland. Ministry of Agriculture, Mbabane, Swaziland.

Narke, S. R., Parulekar, Y., R., Haldavaneker, P. C., Haldankar, P. M., Dhopawkar, R. V., \& Hinge, S. S. (2015). Effect of spacing and fertilizer levels on growth and yield of zucchini under konkan agro-climatic. Indian Journal of Society and Coastal Agricultural Research, 33(2), 22-27.

Ng'etich, O. K., .Niyokuri, A. N., Rono, J. J., Fashaho, A., \& Ogweno, J. O. (2013). Effects of different rates of nitrogen fertilizer on the growth and yield of zucchini (Curcubita pepo cv Diamant L.) Hybrid F1 in Rwandan high altitude zone. International Journal of Agriculture and Crop Sciences, 5(1), 54-62.

Payne, R. W. (2009). 'Genstat'. Wiley Interdisciplinary reviews: Computional Statistics, 1, 255-258. https://doi.org/10.1002/wics.32

Rodrigo, O. M., Eric, B. D., Del-Vall, E. K., Roberto, L. C., \& Horacio, P. M. (2012). Evaluation of three organic fertilizers for growing the widely cultivated crop Cucurbita pepo L. African Journal of Agricultural Research, 7(7), 1087-1097. https://doi.org/10.5897/AJAR11.1166

Rouphael, Y. (2006). Comparison of the subirrigation and drip-irrigation system for greenhouse zucchini squash production using saline and non-saline nutrient solution. Journal of Agricultural Water Management, 82(1-2), 99-117. https://doi.org/10.1016/j.agwat.2005.07.018

Rouphael, Y., \& Colla, G. (2005). Growth, yield, fruit quality and nutrient uptake of hydroponically cultivated zucchini squash as affected by irrigation systems and growing. Scientia Horticulturae, 105(2), 177-195. https://doi.org/10.1016/j.scienta.2005.01.025

Rouphael, Y., \& Colla, G. (2009). The influence of drip irrigation or sub irrigation on zucchini squash grown in closed-loop substrate culture with high and low nutrient solution concentrations. Journal of HortScience, 44(2), 306-311. https://doi.org/10.21273/HORTSCI.44.2.306

Rouphael, Y., Battistelli, A., Rea, E., Colla, G., Moscatello, S., \& Proietti, S. (2004). Yield, water requirement, nutrient uptake and fruit quality of zucchini squash grown in soil and closed soilless culture. Journal of HortScience and Biotechnology, 79(3), 423-430. https://doi.org/10.1080/14620316.2004.11511784

RSA DEPARTMENT OF AGRICULTURE. (2011). Squash Cucurbita moschata production Guide. Pretoria. Republic of South Africa.

Saáata, A., \& Stepaniuk, R. (2012). The effect of irrigation on zucchini cultivar 'Soraya' yielding. Journal HortScience, 3, 21-28.

Schonbeck, B. M., \& Farmer, V. B. (2010). Summer Squash and Zucchini : Organic Production in Virginia VABF Summer Squash Field Trials in Virginia. Viginia Department of Agriculture.

Shaw, N., \& Cantlife, D. J. (2005). Hydroponic greenhouse production of 'Baby' Squash: Selection of suitable squash types and cultivars. Hort-Technology, 15, 722-728. https://doi.org/10.21273/HORTTECH.15.3.0722

Sihlongonyane, S. A., Oseni, T. O., Wahome, P. K., Masarirambi, M. T., \& Kunene, E. N. (2018b). Effects of different media and cultivars on the yield and quality of tomato (Solanum lycopersicum L.) grown in hydroponics. American Eurasian Journal of Agriculture and Environmental Science, 18(6), 338-346.

Sihlongonyane, S. A., Oseni,T. O., Wahome, P. K., Masarirambi, M. T., \& Kunene, E. N. (2018a). Effects of different media and cultivars on the vegetative growth of tomato (Solanum lycopersicum L.) grown in 
hydroponics. American Eurasian Journal of Agriculture and Environmental Science, 18(5), 282-288.

Steel, R. R. D. J., Torrie, H., \& Dickey, D. (1997). Principles and procedures of statistics. A biometrical approarch 3rd ed.McGraw-Hill, Newyork, USA.

Suvo, T. P., Ahamed M. T., Haque, M. R., Chakrobarti, M., \& Biswas, H. (2016). Identification of suitable media based on hydroponic culture for production of zucchini squash. International Journal of Agricicultural Reseasrch Innovation Technology, 6(2), 1-4. https://doi.org/10.3329/ijarit.v6i2.31695

Wahome P. K., Masarirambi, M. T., \& Shongwe, V. D. (2010). Evaluating different hydroponics systems for growth, flowering and quality of gladiolus (Gladiolus grandiflorus). International Journal of Agriculture and Biology, 12(5), 649-654.

Wahome, P. K., Masarirambi, M. T. \& Shongwe, V. D. (2011). Effects of different hydroponics systems and growing media on the vegetative growth, yield and cut flower quality of gypsophila (Gypsophila paniculata L.). World Journal of Agricultural Sciences, 7(6), 692-698. Retrieved from https://www.idosi.org

Wang, D. C. H., Cai, L., Gao, H. Y., Pan, H. Y. X., Xiang, H., \& Deng, M. (2007). Cucurbitane and hexanorcucurbitane glycosides from the fruits of Cucurbita pepo cv. dayangua. International Proceedings of Chemical, Biological and Environmental Engineering, 9(6-8), 525-529. https://doi.org/10.1080/10286020600782538

Xu, H. L., Mridha, M. A. U., Goyal, S., Wang, R., \& Xu, R. Y. (2005). Yield and quality of leafy vegetables grown with organic fertilisations. Acta Horticulture, 13, 25-23.

Yoshida, S., Eguchi, H., \& Kitano, M. (1997). Water uptake and growth of cucumber plants (Cucumis sativus L.) under control of dissolved oxygen concentrations in hydroponics. Acta Horticulture, 440, 199-204. https://doi.org/10.17660/ActaHortic.1996.440.35

\section{Copyrights}

Copyright for this article is retained by the author(s), with first publication rights granted to the journal.

This is an open-access article distributed under the terms and conditions of the Creative Commons Attribution license (http://creativecommons.org/licenses/by/4.0/). 